\title{
Electronic Signatures And The Statute Of Frauds
}

William A. Bottiglieri, (Email: wbottiglieri@iona.edu), Iona College

\begin{abstract}
The Statute of Frauds requires that certain contracts be signed. In this age of e-commerce exactly how does one "sign" a fax or an e-mail.
\end{abstract}

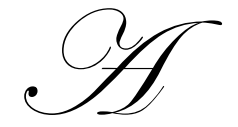

great deal can be accomplished over the Internet: A few well placed keystrokes can send us to exotic places, requisition goods and services, find employment and educate us. Is it possible to make a contract for the sale of real property via e-mail?

So was the question posed by the Court in Rosenfeld v. Zerneck. ${ }^{1}$

In that case, plaintiff and defendant had discussed and had exchanged e-mails negotiating for the sale of defendant's home to plaintiff. Plaintiff interpreted the sum and substance of these messages, when taken together, as an agreement of all of the essential terms of the bargain and viewed this as a contract. Defendant disagreed and moved for summary judgment dismissing the complaint that sought specific performance of this alleged contract. Defendant argued that the e-mail messages were merely preliminary and were never intended to be the final agreement which, he argued, required further discussion. Accordingly, defendant claimed that this e-mail did not satisfy the Statute of Frauds.

During their dealings, after viewing the property, plaintiffs informed the defendant that they "loved the house" and offered a $\$ 3,500,000$ cash deal. They followed up with an e-mail to the defendant.

The correspondence went as follows:

Dear Michael and Liz,

I am glad I had an opportunity to speak with Michael last night. Debbie, Zachary, Noah and I loved your home and its warmth and wish to confirm our firm $\$ 3,500,000$ all cash offer, subject to normal property inspections. Moreover, we see no problem with your desire to close about July 1, 2004. This is our best offer and, as you know, it is net of any broker fees. We look forward to hearing from you at your earliest convenience.

Best Regards,

Tom \& Debbie Rosenfeld

(Defendant's name, address and telephone number were typed in.) $)^{2}$

A brief conversation between the parties followed, after which defendant sent the following e-mail message:

Dear Tom \& Debbie,

This note is to confirm yesterday's telephone conversation in which I accepted your all cash offer of $\$ 3,525,000$ for 18 PPW, with no contingencies for financing or sale of your present residence, to close no later than July 1, 2004. As we discussed, please contact Liz early next week to schedule your inspection. My attorney will prepare a contract 
of sale, to be signed after your engineer's report. (What is the contact information for your attorney? Will you be making the purchase jointly? What is your present address?) "We look forward to continuing cordial relations regarding the sale of this very special home to you and your family.

With kind regards,

Michael." ${ }^{3}$

The Court indeed began its analysis of these facts under the Statute of Frauds but not on the grounds asserted by the defendant. It raised an issue which had not been mentioned by either party, i.e. while there was a writing covering the subject matter of the alleged contract, did this writing contain the required signature of the party to be charged? Did the appendage "(signed) 'Michael" " at the end of his e-mail message constitute the defendant's signature?

The Court reviewed the New York Court of Appeals decision in Parma Tile Mosaic \& Marble Co. v. Estate of Short ${ }^{4}$ for guidance. In Parma Tile the facts concerned a guaranty of payment recited in a fax transmission. The issue was whether the automatic imprinting by fax of the sender's name at the top of each transmitted page satisfied the Statue of Frauds requirement that the certain documents be signed by the party to be charged. The sender had programmed the fax machine to automatically imprint the name of his company, a telephone number and other information at the top of each page as it was being transmitted so that this information appeared on the recipient's fax copy and not on the originating document. The Court held that such an imprint did not constitute a signature as required by the Statute of Frauds because there was no affirmative act by the sender to authenticate that particular transmisison.

As former Chief Judge Cardozo has observed, a signature for Statute of Frauds purposes may be "a name, written or printed, [but] is not to be reckoned as a signature unless inserted or adopted with an intent, actual or apparent, to authenticate a writing" ( Mesibov, Glinert \& Levy v Cohen Bros. Mfg. Co., 245 NY 305, 310; see also, Crabtree v Elizabeth Arden Sales Corp., 305 NY 48, 53-54; La Mar Hosiery Mills v Credit \& Commodity Corp., 28 Misc 2d 764). ${ }^{5}$

The Court went on to find that the requisite intent to authenticate the writing was not present, particularly given the amendment of Section 5-701 of the General Obligations Law in 1994 to provide that: "the tangible written text produced by telex, telefacsimile, computer retrieval or other process by which electronic signals are transmitted by telephone or otherwise shall constitute a writing and any symbol executed or adopted by a party with the present intention to authenticate a writing shall constitute a signing". ${ }^{6}$

In Rosenfeld the Court applied this rationale in finding otherwise on the facts before it. Noting that the failure to satisfy the Statute of Frauds in Parma was not due to the correspondence being sent electronically but rather was due to the sender not adopting or authenticating that particular correspondence, the Court held that in the case before it "the sender's act of typing his name at the bottom of the e-mail manifested his intention to authenticate this transmission for Statute of Frauds purposes and the copy of the e-mail in question submitted as evidence by the defendant constitutes a sufficient demonstration of same". 7 The Court went on to find that the correspondence bwtween the parties did not sufficiently recite all of the essential terms of the agreement and on that basis ultimately dismissed plaintiff's claim.

Other statutory provisions in New York and also on the federal level address the validity of electronic signatures in dealing with contract modifications governed by the Statute of Frauds. Under New York law, in order to be binding on the promisor any agreement that is not to be performed within one year from the making thereof must be in writing and signed by the party to be charged therewith or some person lawfully authorized by him. ${ }^{8}$ When a contract is required by the Statute of Frauds to be in writing, any modification of the contract must also be in writing. ${ }^{9}$

The enforceability of a contract or contract modification made through e-mail communications is governed by federal and state statutes. With regard to transactions in or affecting interstate commerce, the federal Electronic 


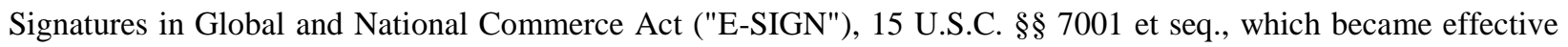
October 1, 2000, provides, in relevant part, that:

Notwithstanding any statute, regulation, or other rule of law ..., with respect to any transaction in or affecting interstate or foreign commerce-

(1) a signature, contract, or other record relating to such transaction may not be denied legal effect, validity, or enforceability solely because it is in electronic form; and

(2) a contract relating to such transaction may not be denied legal effect, validity, or enforceability solely because an electronic signature or electronic record was used in its formation. ${ }^{10}$

The term "electronic" is defined in E-SIGN to mean "relating to technology having electrical, digital, magnetic, wireless, optical, electromagnetic, or similar capabilities." ${ }^{11}$ An "electronic record" is "a contract or other record created, generated, sent, communicated, received, or stored by electronic means." ${ }^{12}$ An "electronic signature" is "an electronic sound, symbol, or process, attached to or logically associated with a contract or other record and executed or adopted by a person with the intent to sign the record." ${ }^{13}$

The Electronic Signatures and Records Act (ESRA), N.Y. Tech. Law $\S \S 303$ et seq. (McKinney 2004), effective March 26, 2000, has been held to be consistent with, and, thus, not preempted by E-SIGN. ${ }^{14}$ The New York Act provides, relevant to the Statute of Frauds issue involved in this instance:

The use of an electronic signature as defined in ESRA shall have the same validity and effect as the use of a signature affixed by hand. ${ }^{15}$

An "electronic signature" is "an electronic sound, symbol, or process, attached to or logically associated with an electronic record and executed or adopted by a person with the intent to sign the record." 16

Although roughly contemporaneous with the Uniform Electronic Transactions Act (the "Uniform Act"), ${ }^{17}$ the New York Act is considerably narrower than the Uniform Act, which New York has not adopted. Section 7(c) and (d) of the Uniform Act provides:

(c) If a law requires a record to be in writing, an electronic record satisfies the law.

(d) If a law requires a signature, an electronic signature satisfies the law. ${ }^{18}$

The express purpose of these subsections is to "provide the positive assertion that electronic records and signatures satisfy legal requirements for writings and signatures." 19 The following illustrations to $\S 7$ of the Uniform Act make clear that e-mails can constitute sufficient records and signatures to satisfy the Statute of Frauds, so long as the e-mails otherwise satisfy the requirements of an enforceable contract or contract modification:

Illustration 1: A sends the following e-mail to B: "I hereby offer to buy widgets from you, delivery next Tuesday. /s/ A." B responds with the following e-mail: "I accept your offer to buy widgets for delivery next Tuesday. /s/ B." The e-mails may not be denied effect solely because they are electronic. In addition, the e-mails do qualify as records under the Statute of Frauds. However, because there is no quantity stated in either record, the parties' agreement would be unenforceable under existing UCC Section 2-201(1).

Illustration 2: A sends the following e-mail to B: "I hereby offer to buy 100 widgets for $\$ 1,000$, delivery next Tuesday. /s/ A." B responds with the following e-mail: "I accept your offer to purchase 100 widgets for $\$ 1000$, delivery next Tuesday. /s/ B." In this case the analysis is the same as in Illustration 1 except that here the records otherwise satisfy the requirements of UCC Section 2-201(1). The transaction may not be denied legal effect solely because there is not a pen and ink "writing" or "signature." 20

With regard to the critical issue for the Statute of Frauds or what constitutes a "signature," E-SIGN, the New York Act, and the Uniform Act all focus on the person's use of a symbol that is attached to or logically 
associated with a record with the intent to sign the record. ${ }^{21}$ Although there is little or no elaboration for this requirement in E-SIGN or the New York Act, the Uniform Act clearly indicates that, while the issue of whether any particular record was intended to be "signed" is a question of fact; ${ }^{22}$ an electronic record and signature are both attributable to a person who simply types his name as part of an e-mail that otherwise satisfies the requirements of an enforceable contract or contract modification. ${ }^{23}$

The courts that have considered the question have generally concluded that e-mails may satisfy the writing and signature requirements of the Statute of Frauds, even as to those transactions that are not covered by E-SIGN either because they are not in or affecting interstate commerce or because they occurred before E-SIGN took effect in $2000 .^{24}$ Notably, Judge Posner's opinion in the Hasbro case dealt specifically with the enforceability of contract modifications made through e-mail communications. Thus, the Statute of Frauds should not pose a bar to the enforceability of a contract or contract modification made through e-mail communications, so long as the contents of the e-mails satisfy the other requirements imposed by law in addition to writings and signatures. ${ }^{25}$

\footnotetext{
${ }^{1} 4$ Misc. 3d 193, 776 N.Y.S. 2d 458 (2004).

${ }^{2}$ Rosenfeld, supra at 194.

${ }^{3}$ Rosenfeld, supra at 194, 195.

${ }^{4} 87$ N.Y.2d 524, 663 N.E.2d 633, N.Y.S.2d 477 [1996]

${ }^{5}$ Parma, supra, at 527.

${ }^{6}$ General Obligations Law § 5-701 [b] [4].(emphasis supplied).

${ }^{7}$ Rosenfeld, supra at $195,196$.

${ }^{8}$ N.Y. Gen. Oblig. Law $§ 5-701(a)(1)$ (McKinney 2002)

${ }^{9}$ See Holland v. Ryan, 307 A.D.2d 723, 762 N.Y.S.2d 740, 741 ( $4^{\text {th }}$ Dep't 2003).

${ }^{10} 15$ U.S.C. $\$ 7001$ (a).

${ }^{11}$ Id. $\$ 7006(2)$.

${ }^{12}$ Id. $\$ 7006(4)$.

${ }^{13} I d . \$ 7006(5)$.

${ }^{14}$ See People v. McFarlan, 191 Misc. 2d 531, 744 N.Y.S.2d 287 (Sup. Ct. 2002).
}

${ }^{15}$ N.Y. Tech. Law $\S 540.4(a)$; see 61 N.Y. Jur. Frauds, Statute of $§ 201$ (2006) ("[U]nless specifically provided otherwise by law, an electronic signature may be used by a person in lieu of a signature affixed by hand. The use of an electronic signature has the same validity and effect as the use of a signature affixed by hand").

${ }^{16}$ N.Y. Tech. Law $\$ 540.4($ b).

17 7A Pt. I U.L.A. 211 (2002)

187 A Pt. I U.L.A. 252.

${ }^{19}$ Uniform Act $\S 7$ cmt. 3, 7A Pt. I U.L.A. 253.

${ }^{20} I d$.

${ }^{21}$ See 15 U.S.C. § 7006(5); N.Y. Tech. Law § 302(3); Uniform Act § 2(8), 7A Pt. I U.L.A. 226.

${ }^{22}$ see Uniform Act $\S 2 \mathrm{cmt}$. 7, 7A Pt. I U.L.A. 229

${ }^{23}$ See Uniform Act $\$ 9$ cmt. 1, 7A Pt. I U.L.A. 261; see also Cloud Corp. v. Hasbro, Inc., 314 F.3d 289, 296 (7th Cir. 2002) (Posner, J.) (sender's name on e-mail satisfies the signature requirement of the Statute of Frauds); Rosenfeld v. Zerneck, 4 Misc. 3d 193, 776 N.Y.S.2d 458, 460 (Sup. Ct. 2004) (sender's act of typing his name at bottom of e-mail manifested his intention to authenticate transmission for purposes of Statute of Frauds); Shattuck v. Klotzbach, No. 011109A, 14 Mass. L. Rptr. 360 , 2001 WL 1839720, at *2-*3 (Mass. Super. Ct. Dec. 11, 2001) (a reasonable trier of fact could conclude that e-mails sent by the defendant with his typed name at the end were "signed" with the intent to authenticate the information contained therein as his act).

${ }^{24}$ See, e.g., Hasbro, 314 F.3d at 295; Roger Edwards, LLC v. Fiddes \& Son, Ltd., 245 F. Supp. 2d 251, 261 (D. Me. 2003 ) (citing cases); Shattuck, 2001 WL 1839720, at *2-*3. See generally John E. Theuman, Annotation, Satisfaction of Statute of Frauds by E-Mail, 110 A.L.R.5th 277 (2004); 10 Samuel Williston, A Treatise on the Law of Contracts § 29:23 (Richard A. Lord 4th ed. 1999).

${ }^{25}$ Cf. General Trading Int'l, Inc. v. Wal Mart Stores, Inc., 320 F.3d 831, 836-37 (8th Cir. 2003) (the language in the parties' emails did not constitute a sufficient writing for purposes of the Statute of Frauds because it did not evince any agreement between the parties on price markdowns); Hugh Symons Group, PLC v. Motorola, Inc., 292 F.3d 466, 470 (5th Cir.) (no contract formed by e-mail where communications merely exchanged preliminary information and there was no language expressing or contemplating a final agreement or settling on terms), cert. denied, 537 U.S. 950 (2002); Rosenfeld, 776 N.Y.S.2d at 461 (although sufficient for Statute of Frauds purposes, e-mail did not constitute binding contract because it failed to lay out all of the essential terms of the parties' agreement, thus demonstrating that there was no meeting of the minds between the parties). 